\title{
ANALISIS USAHA KELOMPOK TANI TERNAK SAPI “PELITA” DI DESA TONSEWER KECAMATAN TOMPASO BARAT KABUPATEN MINAHASA
}

\author{
Jentry S. Lahe Arbi*, M.A.V. Manese, I.R.D. Lumenta dan M.L. Rundengan
}

\begin{abstract}
ABSTRAK
Penelitian ini bertujuan menganalisis break even point (BEP) pada usaha tani ternak sapi PO "Kelompok Pelita" di Desa Tonsewer. Penelitian ini menggunakan metode survey dengan data primer dan sekunder. Data dikumpulkan pada bulan september sampai oktober 2015, menggunakan analisis BEP. hasil penelitian, menunjukkan bahwa pemeliharaan 63 ekor ternak sapi selama 1 tahun, mengeluarkan biaya total Rp. 414.150.000-, dengan penerimaan yaitu Rp.714.246.250, dan BEP penerimaan yaitu Rp.62.265.476,19 dan BEP produksi yaitu 6 ekor ternak sapi.
\end{abstract}

Kata Kunci : Ternak Sapi, Kelompok Tani Ternak, BEP

\section{ABSTRACT}

ANALYSIS GROUP BUSINESS FARM ANIMALS CATTLE " PELITA " IN THE VILLAGE Tonsewer Tompaso WEST DISTRICT MINAHASA The aim of this research, analyzing the break even point (BEP) in cattle farming PO "Pelita Group" in the village Tonsewer. This study used

Korespondensi (correspondence)

Email : jentry_sutriady@yahoo.com survey method with primary and secondary data. Data were collected from September to October 2015, using the BEP analysis. Results of the study showed that the maintenance of 63 head of cattle during the first year, issued a total cost of Rp. 414.150.000-, with revenues of Rp. 714246 250, and BEP revenues of Rp. 62,265,476.19 and BEP production is 6 head of cattle.

\section{Keywords : Catlle, Farmer Group, BEP.}

\section{PENDAHULUAN}

Permintaan pangan hewani hasil ternak (daging, telur, dan susu) dari waktu ke waktu cenderung meningkat sejalan dengan pertumbuhan jumlah penduduk, peningkatan pendapatan, kesadaran gizi dan tingkat pendidikan yang lebih baik. Sementara pasokan sumber protein hewani terutama daging sapi masih belum dapat mengimbangi meningkatnya jumlah permintaan ternak sapi dalam negeri baik kualitas maupun kuantitas. 
Kondisi ini tercermin pada impor ternak sapi bakalan maupun daging sapi yang cenderung meningkat (Subagio, 2009).

\section{Program peningkatan}

populasi ternak sapi serta produktifitasnya belum cukup. Hal ini disebabkan karena kendala perkembangan populasi ternak sapi tidak hanya disebabkan oleh serangan penyakit, mortalitas yang tinggi atau adanya gangguan reproduksi. Kendalah yang dihadapi juga bagaimana merubah kondisi sosial ekonomi rumah tangga petani untuk dapat meningkatkan jumlah ternak sapi yang dipelihara atau dimiliki. Program meningkatkan populasi ternak sapi diupayakan guna meningkatkan pendapatan petani sekaligus memberikan peranan dalam pertumbuhan ekonomi di pedesaan.

Ternak sapi mempunyai posisi strategis dalam pembangunan pertanian/peternakan serta kesejahteraan masyarakat. Artinya bahwa pembangunan peternakan sapi bukan hanya bermaksud meningkatkan produksi daging atau susu lokal maupun nasional tetapi sekaligus menyediakan sumberdaya pupuk kandang, tenaga kerja dan sebagai sumber tambahan pendapatan (Akhmad. S dan Machfudin. B, 2012). Ternak sapi PO di Sulawesi Utara telah dijadikan sebagai ternak sapi andalan yang ditetapkan pemerintah daerah dalam rangka meningkatkan pertumbuhan ekonomi daerah khususnya dari subsektor peternakan. Jumlah populasi ternak sapi di Sulawesi Utara pada tahun 2014 adalah 105.841 ekor dan jumlah populasi terbanyak terdapat di wilayah Kabupaten Minahasa sebanyak 17.270 ekor (BPS Sulut 2014).

Kecamatan Tompaso barat cocok untuk usaha peternakan sapi karena masih banyak lahan yang belum dimanfaatkan. Hal ini terutama perkebunan masyarakat yang tidak diolah sehingga bisa digunakan untuk menggembalakan ternak sapi. Daerah ini merupakan wilayah dengan populasi ternak sapi terbanyak di Kabupaten Minahasa yaitu berjumlah 2.676 ekor (data dinas peternakan Kabupaten Minahasa tahun 2014).

Menurut Yusdja. dan Ilham. 2004. Usaha ternak sapi sudah 
dikenal oleh masyarakat pedesaan, diantaranya masyarakat Desa Tonsewer. Desa Tonsewer memiliki kelompok ternak sapi yaitu kelompok Pelita yang didirikan pada tanggal 15 Januari tahun 2005 dan disahkan oleh BP3K (Balai Penyuluh Pertanian Perkebunan Perikanan Kecamatan). Pada tahun 2014 kelompok tani ternak Pelita memiliki 44 ekor ternak sapi dan pada tahun 2015 ternak sapi telah berkembang menjadi 63 ekor dengan rincian 19 ekor ternak pedet, 3 ekor sapi dara, dan 41 ekor sapi dewasa. Pemeliharaan ternak sapi dengan cara digembalakan, jenis ternak sapi yang dipelihara sapi (PO). Kegiatan yang diikuti oleh kelompok Pelita yaitu Vaksinator tahun 2009, BIMTEK Peningkatan Kapasitas Petugas Teknik IB Angkatan VII tahun 2012 dan BIMTEK PKB ATR Tingkat Nasional Angkatan II tahun 2013. Permasalahannya apakah usaha ternak sapi bagi kelompok tani ternak "Pelita" sudah memberikan keuntungan yang memadai atau masih pada posisi pulang pokok. Tujuan penelitian adalah untuk menganalisis Break Even Point (BEP) usaha ternak sapi potong milik anggota usaha kelompok tani ternak sapi potong Pelita di Desa Tonsewer Kecamatan Tompaso Barat Kabupaten Minahasa.

\section{METODE PENELITIAN}

Penelitian ini dilakukan di Desa Tonsewer Kecamatan Tompaso Barat Kabupaten Minahasa pada Kelompok Tani Ternak Sapi Pelita. Waktu penelitian mulai dari tanggal 5 September 2015 sampai dengan 5 Oktober 2015. Metode yang digunakan dalam penelitian ini adalah metode survei yaitu pengamatan langsung pada kelompok usaha tani ternak sapi Pelita di Desa Tonsewer Kecamatan Tompaso Barat Kabupaten Minahasa dengan mengacuh pada daftar pertanyaan atau kosioner. Data yang digunakan dalam penelitian ini adalah data primer dan data sekunder. Data primer diambil dari responden dan yang menyangkut dengan usaha ternak sapi yang ada dalam kelompok usaha tani ternak sapi Pelita. Data sekunder berupa data keadaan umum wilayah, populasi ternak, jumlah penduduk yang diperoleh dari instansi terkait diataranya Badan Pusat Statistik, 
Kabupaten, Kecamatan dan Desa. Responden dalam penelitian ini adalah anggota kelompok tani ternak sapi "Pelita". Analisis data yang digunakan adalah analisis Break Even Point (BEP). Perhitungan biaya tetap dalam penelitian ini dihitung dari biaya penyusutan kandang dan peralatan yang digunakan dengan rumus penyusutan menurut (Prawirokusumo, 1990), seperti pada persamaan (1).

Penyusutan $=\frac{\text { Nilai awal }- \text { Nilai Sekarang }}{\text { Nilai Ekonomis }}$

Penyusutan kandang dihitung dengan menggunakan persamaan (2).

$\underline{\text { Nilai awal Kandang -Nilai sekarang kandang }}$ Nilai ekonomis kandang

(2)

Analisis Break Even Point (BEP) digunakan untuk mengetahui hubungan antara variabel didalam kegiatan perusahaan yakni biaya produksi, volume produksi dan keuntungan yang diperoleh perusahaan. Rumus BEP secara matematis yang digunakan mengacu dari Riyanto (2001) seperti pada persamaan (3).

$\mathrm{BEP}(\mathrm{Rp})=\frac{\text { Fixed cost }}{1-(\text { Variabel cost } / \text { sales }}$

BEP ekor $=$

Total Biaya Tetap

$\overline{\text { Harga jual per ekor-Biaya Variabel/ kuantias produksi(ekor) }}$

\section{HASIL DAN PEMBAHASAN}

Berdasarkan pengamatan, usaha ini menggunakan tenaga kerja anggota kelompok atau yang menjadi anggota kelompok yang sudah terjadwalkan setiap hari 3 orang yang mengurus seluruh ternak sapi, dimana kegiatan yang dilakukan adalah menggiring ternak sapi ke kebun habis dipanen atau lahan yang belum diolah, memberi pakan, minum, membersihkan kandang dan lain-lain yang berhubungan dengan usaha peternakan sapi ini, dalam 1 hari upah yang diberikan sebesar Rp. 75.000,- dan untuk 3 orang upah yang dibrikan selama 1 tahun sebesar Rp. 82.125.000,-

\section{Pemeliharaan ternak sapi PO}

perlu memperhatikan kebersihan kandang dan lokasi dimana ternak itu dipelihara, kandang harus dibersikan setiap hari agar terhindar dari serangan penyakit sehingga ternak tetap sehat. Hasil penelitian menunjukan anggota kelompok hanya memberikan obat cacing dalam 1 tahun Rp. 174.000,- dan vitamin Rp. 76.000,- untuk seluruh ternak.

Alat yang digunakan untuk menunjang kegiatan dikandang 
seperti tempat pakan, tempat air minum, pengangkat kotoran ternak sapi dan lain-lain. Peralatan yang digunakan dalam usaha perternakan kelompok "Pelita" adalah sekop, parang, ember, kabel, arco, tali untuk mengikat ternak sapi. Harga keseluruhan peralatan yang digunakan sebesar Rp. 954.000 per tahun.

Pemasaran ternak sapi PO kelompok ternak sapi Pelita yaitu kepada sesama peternak di Kecamatan dan juga melalui pasar Blante atau pembeli datang langsung kekandang untuk membeli ternak sapi. Harga per ekor sapi pedet jantan 4 juta betina 6 juta, sapi dara jantan 7 juta betina 8 juta, dan sapi dewasa jantan 12 juta betina 15 juta. Harga tersebut menurut umur ternak atau menurut ciri-ciri ternak.

Berdasarkan pada Tabel 1, biaya yang dikeluarkan pada usaha ternak sapi potong PO "Kelompok Pelita" adalah sebesar Rp 26.151.500.

Penyusutan per tahun

$$
\begin{aligned}
& =\frac{\operatorname{Rp} 26.151 .500-0}{10} \\
& =2.651 .150
\end{aligned}
$$

Penyusutan per bulan

$$
=217.929,16
$$

Penyusutan 1 periode $=$ Rp 2.651.150,-

Berdasarkan Tabel 2, biaya tidak tetap yang dikeluarkan usaha ternak sapi PO" Kelompok Pelita" berupa biaya bibit, pakan, obatobatan, listrik, transportasi dan TK sebesar RP. 414.150.000,- per tahun

Penerimaan ialah jumlah uang dari hasil penjualan ternak sapi (Rp/ekor) dan penjualan kotoran ternak (pupuk kompos). Hasil penelitian menunjukan bahwa penjualan ternak sapi pada "Kelompok Pelita" dengan jumlah ternak sapi 63 ekor dengan rincian seperti tercantun pada Tabel 3. 
Tabel 1. Biaya Tetap Usaha Sapi PO Kelompok Tani Ternak "Pelita" per Periode

\begin{tabular}{clccrr}
\hline No & Jenis Biaya & Jumlah & Satuan & Harga & \multicolumn{1}{c}{$\begin{array}{l}\text { Jumlah } \\
(\mathbf{R P})\end{array}$} \\
\hline 1 & Kandang & 1 & Unit & - & 18.867 .500 \\
2 & Kabel & 589 & Meter & 11.000 & 6.479 .000 \\
3 & Ember & 4 & Unit & 15.000 & 60.000 \\
4 & Sekop & 2 & Unit & 35.000 & 70.000 \\
5 & Lampu & 3 & Unit & 25.000 & 75.000 \\
7 & Tali Nilon & 6 & Kg & 300.000 & 300.000 \\
8 & Arco & 1 & Unit & 300.000 & 300.000 \\
\hline \multicolumn{2}{r}{ Total } & & & & $\mathbf{2 6 . 1 5 1 . 5 0 0}$ \\
\hline
\end{tabular}

Tabel 2. Biaya Tidak Tetap Usaha Ternak Sapi PO Kelompok Tani Ternak "Pelita"

\begin{tabular}{clccrr}
\hline No & \multicolumn{1}{c}{ Jenis Biaya } & Jumlah & Satuan & $\begin{array}{c}\text { Harga } \\
\text { (Rp/tahun) }\end{array}$ & \multicolumn{1}{c}{$\begin{array}{c}\text { Jumlah } \\
\text { (Rp/tahun) }\end{array}$} \\
\hline 1 & Bibit & 44 & Ekor & $4.909 .090,90$ & 216.000 .000 \\
2 & Pakan & 22.995 & Ikat & 5000,00 & 114.975 .000 \\
3 & Obat-obatan \& Vitamin & & & $250.000,00$ & 250.000 \\
4 & Listrik & & & $300.000,00$ & 300.000 \\
5 & Transportasi & & & $500.000,00$ & 500.000 \\
6 & TK & 3 & Orang & $27.375 .000,00$ & 82.125 .000 \\
\hline \multicolumn{7}{r}{ Total } & & $\mathbf{4 1 4 . 1 5 0 . 0 0 0}$ \\
\hline
\end{tabular}

Tabel 3. Jumlah ternak sapi dengan harga jual kelompok tani ternak "Pelita"

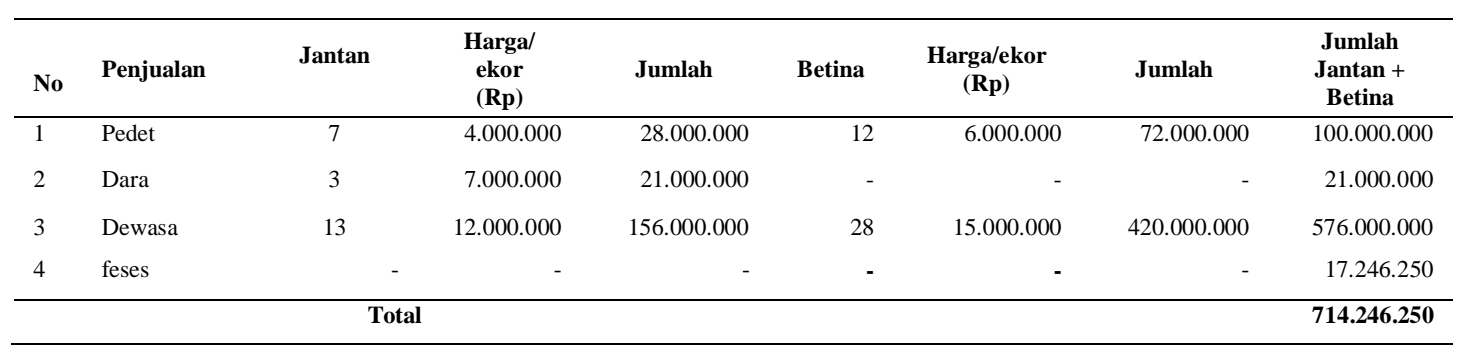

Berdasarkan Tabel 3 terlihat bahwa jumlah ternak sapi Pedet 19 ekor, Dara 3 ekor, Dewasa 31 ekor sehingga diperoleh sebesar Rp.
697.000.000,- per periode ditambah dengan penjualan feses ternak dengan produksi feses $3 \mathrm{~kg} / \mathrm{ekor} / \mathrm{hari}$ selama 1 tahun, harga feses per $\mathrm{kg}$ sebesar 
Rp.250 dan total keseluruhan selama 1 tahun untuk penjualan feses sebagai pupuk kompos sebesar Rp.17.246.250, sehingga jumlah keseluruhan penerimaan kelompok tani ternak "Pelita" sebesar Rp.714.246.250,- per tahun. Jumlah rata-rata dalam penjualan 63 ekor ternak sapi sebesar Rp.11.063.492,06.

Tujuan utama usaha ternak sapi oleh kelompok tani ternak "Pelita" adalah untuk memperoleh keuntungan. Menurut Prawirokusumo (1990), Ryanti (2011). Keuntungan adalah jumlah rupiah yang diperoleh dari pendapatan bersih suatu usaha.

Keuntungan merupakan selisih antara nilai penerimaan total dengan biaya (biaya tetap dan biaya tidak tetap). Keuntungan yang diperoleh dari suatu usaha akan semakin besar bila selisih antara nilai penerimaan dan nilai biaya semakin besar. Semakin besar keuntungan yang diterima, semakin layak suatu usaha peternakan dikembangkan (Soekartawi, 2002).

Keuntungan yang diperoleh dari hasil penjualan sapi PO sebanyak 63 ekor dan penjualan kotoran sapi sebagai pupuk kompos per periode sebanyak Rp. 273.944.750,- per tahun. Analisis Break Even Point (BEP) merupakan salah satu teknis analisis ekonomi yang berguna dalam hubungan biaya variabel (TVC) dan biaya tetap total (TFC) terhadap output produksi atau ukuran-ukuran lain dalam aktifitas bisnis dan industri (Gasperesz, (2002), Zaini, (2007). Analisis Break Even Point (BEP) digunakan untuk mengetahui hubungan antara variabel didalam kegiatan perusahaan yakni biaya produksi, volume produksi dan keuntungan yang diperoleh perusahaan. Berdasarkan analisis keuntungan yang telah dilakukan, diperoleh Rp. 269.658.500 ,- dari penjualan kotoran ternak sebagai pupuk kompos dan dari penjualan ternak sapi sebanyak 63 ekor. Sehingga, dapat dikatakan usaha ternak sapi PO"Kelompok Pelita" sudah mencapai BEP, karena perushaan sudah mengalami keuntungan. Analisis Break Even Point (BEP) penerimaan dengan menggunakan rumus menurut Riyanto 
(2001), dapat dilihat pada perhitungan selanjutnya.

Berdasarkan hasil analisis BEP

$$
\begin{aligned}
\operatorname{BEP}(\operatorname{Rp}) & =\frac{26.151 .500}{1-\frac{414.150 .000}{714.246 .250}} \\
& =\frac{26.151 .500}{1-0,57} \\
& =\frac{26.151 .500}{0,43} \\
& =60.817 .441,86
\end{aligned}
$$

Berdasarkan hasil analisis BEP penerimaan diperoleh nilai 60.817.441,86. Artinya usaha ternak sapi PO mencapai pulang pokok pada saat usaha "Kelompok Pelita" memperoleh penerimaan sebesar Rp. 60.817.441,86. volume diperoleh nilai BEPnya sebesar 5,82 ekor. Artinya usaha ternak sapi PO mencapai pulang pokok apabila memelihara ternak sapi PO sebanyak 5,82 ekor.

Kondisi nilai BEP penerimaan dan volume dengan menggunakan rumus BEP menurut Riyanto (2001), sesuai dengan perhitungan atau analisis Total Revenue (TR) dan Total Variabel Cost (TVC) dengan menggunakan grafik. Grafik BEP dapat dilihat pada Gambar 1.

Analisis Break Even Point (BEP) volume dengan menggunakan rumus menurut Riyanto (2001), dapat dilihat pada perhitungan selanjutnya.

$$
\begin{aligned}
\operatorname{BEP}(\text { ekor }) & =\frac{26.151 .500}{11.063 .492,06-\frac{414.150 .000}{63}} \\
& =\frac{26.151 .500}{11.063 .492,06-6.573 .809,52} \\
& =\frac{26.151 .500}{4.489 .682,54} \\
& =5,82
\end{aligned}
$$




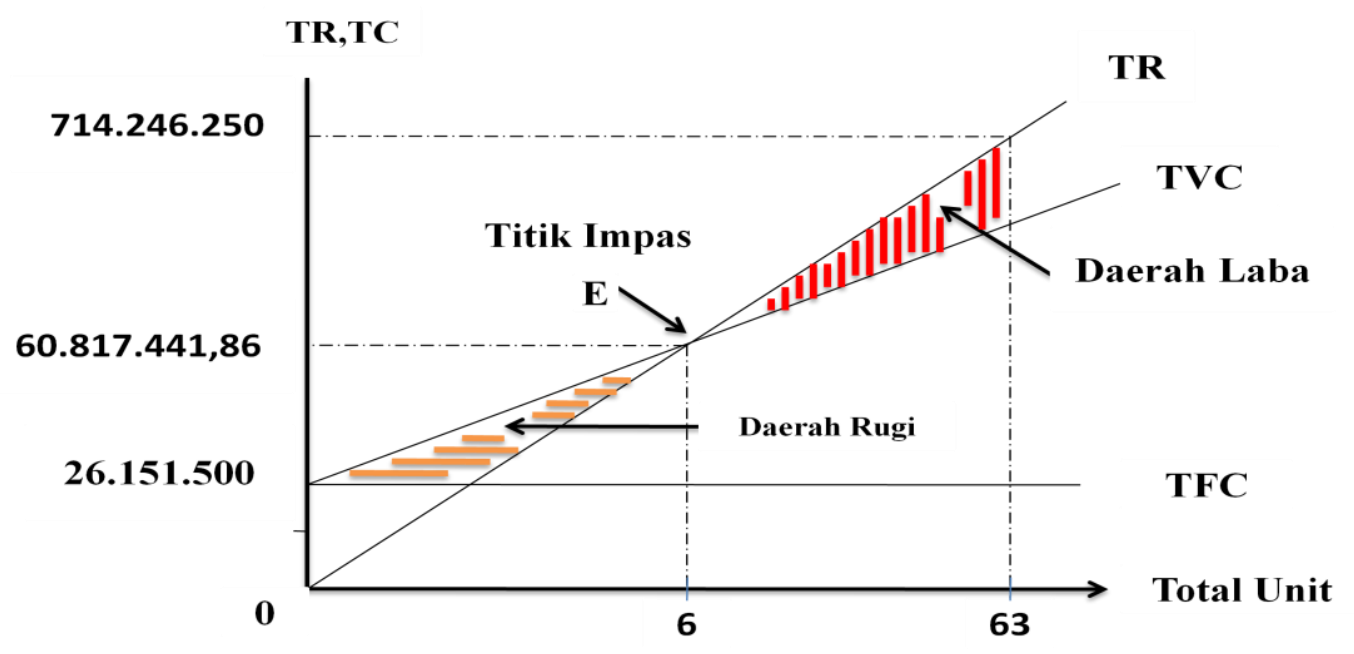

Gambar 1. Grafik Break Even Point

Ket.

TR = Total Revenue

$\mathrm{TC}=$ Total Cost

TVC = Total Variabel Cost

TFC $=$ Total Fixed Cost

Grafik BEP dapat diketahui nilai penjualan, kuantitas penjualan,biaya variabel, biaya tetap, laba marginal, laba atau rugi pada tingkat penjualan tertentu, dan titik BEP. Berdasarkan Gambar 1 dijelaskan sebagai berikut.

a. Garis vertikal menunjukan biaya dan juga hasil penjualan total dalam rupiah atau sebesar Rp. 714.246.250,- dan biaya sebesar Rp. 440.301.500,-

b. Garis horizontal menunjukan kuantitas yang dijual. Oleh karena harga produk bersifat tetap maka sumbu $\mathrm{X}$ juga dapat menunjukan penjualan dalam rupiah atau pada penjualan 63 ekor.

c. Perusahaan berkapasitas maksimum 63 unit, berarti penjualan maksimum Rp. 714.246.250,-

d. Biaya variabel ditarik dari titik Rp. 26.151.500 Kekanan atas ketitik Rp. 440.301.500,- (yaitu angka yang diperoleh dari biaya tetap Rp. 26.151.500 Ditambah biaya variabel Rp. 414.150.000) Pada penjualan Rp. 714.246.250.

Pertemuan antara garis biaya total dan garis penjualan, yaitu titik E, disebut sebagai titik BEP (breakevent point) dari titik ini ditarik garis lurus kesumbu Y akan diperoleh nilai penjulan BEP yaitu Rp. 
60.817.441,86, dan biaya total juga

Rp. 440.301.500. Dari titk BEP ditarik garis lurus ke sumbu $\mathrm{X}$ akan diperoleh kuantitas penjualan BEP yaitu 6 unit. dari titik BEP kekiri terlihat segitiga yang menunjukan daerah rugi (loss area) dan kekanan terlihat segitiga yang menunjukan daerah laba (profit area).

\section{Kesimpulan}

1. Biaya produksi yang diperoleh dalam pemeliharaan 63 ekor sapi PO sebesar Rp. 414.150.000,-

2. Usaha peternakan sapi PO pada kelompok tani ternak "Pelita" di Desa Tonsewer Kecamatan Tompaso Barat Kabupaten Minahasa mencapai titik impas pada Break Even Point (BEP) penerimaan sebesar Rp. 62.265.476,19 dan BEP produksi sebesar 6 ekor.

\section{DAFTAR PUSTAKA}

Akhmad. S dan Machfudin. B, 2012. Produktivitas Sapi Potong pada Kelompok Tani Ternak di Pedesaan. Fakultas Peternakan Universitas Jenderal Soedirman Jln. Dr. Soeparno, No. 60, Kotak Pos
110 Purwokerto, Jawa-Tengah Badan Pusat Statistik Provinsi Sulawesi Utara. 2014. Sulawesi Utara Dalam Angka.

Gazpersz. V, 2002. Pedoman Penyusutan Rencana Bisnis. PT Gramedia Pustaka Utama. Jakarta.

Hadi, P.U. dan N. Ilham. 2002. Problem dan prospek pengembangan usaha pembibitan sapi potong di Indonesia. Jurnal Penelitian dan Pengembangan Pertanian 21(4): $148-157$

Riyanto, B. 2001. Dasar-dasar pembelanjaan Perusahaan Ed.IV Cet VII. Penerbit BPFEE. Yogyakrta.

Riyanti, I. 2011. Analisis Keuntungan Pembuatan Pupuk Organik (Studi. KasusDi Koperasi Agung Jaya Kec. Pandaan, Kab. Pasuruan).

Riyanti, I. 2011. Analisis Keuntungan Pembuatan Pupuk Organik (Studi. KasusDi Koperasi Agung Jaya Kec. Pandaan, Kab. Pasuruan).

Soekardono, 2009. Ekonomi Agribisnis Peternakan Teori dan Aplikasi. Akademi Presindo.

Soekartawi, 2002.Teori Ekonomi Produksi. PT Raja Grafindo Persada, Jakarta.

Yusdja, Y. dan N. Ilham. 2004. Tinjauan kebijakan pengembangan agribisnis sapi potong. Jurnal Analisis Kebijakan Pertanian 2(2): 167-182 
Zaini, Muhammad. 2007. Analysis of

Income And Break Even

Point of Home Industry Of

Tofu At Punngur Residence.

Jurnal Ilmiah ESAI. Volume

1 , Nomor 1. 